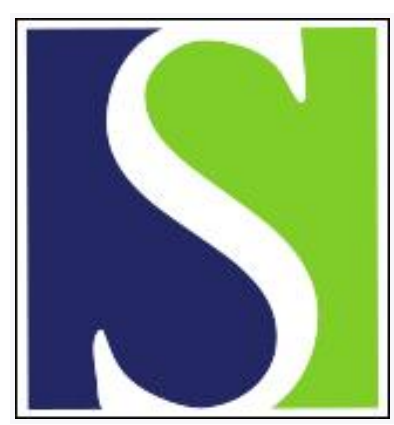

Scand J Work Environ Health 1987;13(1):26-31

https://doi.org/10.5271/sjweh.2088

Issue date: Feb 1987

\title{
Cancer mortality of granite workers.
}

by Koskela RS, Klockars M, Jarvinen E, Kolari PJ, Rossi A

This article in PubMed: www.ncbi.nlm.nih.gov/pubmed/3033818

\section{(c) (1)}




\title{
Cancer mortality of granite workers
}

\author{
by Riitta-Sisko Koskela, MSocSC, Matti Klockars, MD, Erkki Järvinen, MSc, Pertti J Kolari, MSc, \\ Aija Rossi, MSocSc ${ }^{1}$
}

\begin{abstract}
KOSKELA R-S, KLOCKARS M, JÄRVINEN E, KOLARI PJ, ROSSI A. Cancer mortality of granite workers. Scand $J$ Work Environ Health 13 (1987) 26-31. A retrospective cohort study was undertaken to investigate the cancer mortality of granite workers. The study comprised 1026 workers hired between 1940 and 1971. The number of person-years was 20165 , and the number of deaths 235 . During the total follow-up 46 tumors were observed and 44.9 were expected. An exess mortality from tumors was observed for the workers followed for 20 years or more, the greatest excess occurring during the follow-up period of 25-29 years (observed 11, expected 5.2). Of the 46 tumors, 22 were lung cancers (expected $17.1)$ and 15 were gastrointestinal cancers (expected 9.7), nine of which were cancers of the stomach (expected 6.0). Mortality from lung cancer was excessive for workers with at least 15 years since entry into granite work (latency) ( 21 observed and 9.5 expected), being highest during the follow-up period of $25-29$ years (observed 8 , expected 2.1 ). The results indicate that granite exposure per se may be an etiologic factor in the initiation or promotion of malignant neoplasms.
\end{abstract}

Key terms: cohort study, epidemiologic methods, gastrointestinal cancer, granite dust, lung cancer, silicosis.

Bronchial carcinoma occasionally occurs in silicotic lungs, but there is incomplete evidence of a causal relationship between cancer and silicosis or siliceous dusts. Recent epidemiologic data have suggested an excess of lung cancer mortality among silicotic patients $(7,10,28,33)$. From the epidemiologic point of view, these studies are not "clean" because the silica exposure has usually been accompanied by other exposures, eg, in mining (radon daughters) and in foundries (polycyclic aromatic hydrocarbons).

Studies on workers exposed to pure silica dust are rare $(6,29)$. Those that do exist have shown decreased or only slightly higher lung cancer rates than expected. Mortality studies on silica-exposed coal miners suggest a decreased risk for lung cancer but an increased risk for gastrointestinal cancer $(2,23,27)$.

In this paper we report a study in which granite workers exposed to pure silica had an excess cancer mortality.

\section{Subjects and methods}

\section{Subjects}

The study population was composed of Finnish granite workers employed in quarries and processing yards from three different regions of Finland (Vehmaa, Viitasaari and Kuru). The cohort comprised 1026 workers hired for at least three months between 1940 and 1971. The workers' ages ranged from 15 to 72 (median 27) years at the time of entry into the cohort. The

\footnotetext{
1 Institute of Occupational Health, Helsinki, Finland.
}

Reprint requests to: Ms R-S Koskela, Institute of Occupational Health, Topeliuksenkatu 41 a A, SF-00250 Helsinki, Finland. mean exposure time to quartz dust was approximately 12 years.

The workers' names, dates and places of birth, and work history at each firm were collected from the employers' personnel records. The workers were traced through the Population Data Register, and all of them were traced.

The causes of death were ascertained from the death certificates according to the eighth revision of the International Classification of Diseases (25). The histological classification of cancer was obtained from the cancer registry.

\section{Exposures}

A survey of dust, vibration, and noise exposure and the health, disability and mortality of the workers in the Finnish granite industry (quarrying, crushing and block processing) was performed by the Institute of Occupational Health in 1970-1972 $(1,16)$. Dust measurements were made in 28 quarries and processing yards and in four crushing plants. The dust concentrations were high in several stages of the work phases.

The highest concentrations were noted in drilling, the hygienic standard for quartz (for total inorganic dust, $10 \mathrm{mg} / \mathrm{m}^{3}$, and for quartz with an aerodynamic diameter of $<5 \mu \mathrm{m}, 0.2 \mathrm{mg} / \mathrm{m}^{3}$ ) being exceeded, on the average, ten times. The dust concentrations varied with the stage of work, the total dust concentrations ranging from 12 to $116 \mathrm{mg} / \mathrm{m}^{3}$ for drilling, from 4 to $94 \mathrm{mg} / \mathrm{m}^{3}$ for the surfacing of blocks with a pneumatic hammer, and from 0.3 to $90 \mathrm{mg} / \mathrm{m}^{3}$ for other stages of the work. The range of the quartz concentrations was $0.3-4.2 \mathrm{mg} / \mathrm{m}^{3}, 0.2-4.9 \mathrm{mg} / \mathrm{m}^{3}$, and $0.02-3.6 \mathrm{mg} / \mathrm{m}^{3}$ for the drilling, block surfacing and other work phases, respectively (1). 


\section{Basis for comparison}

The mortality of the granite cohort was compared to that recorded for the general Finnish male population in the official statistics on causes of death in 1972 (34). The year 1972 was the median year of the deaths in the cohort (from 1940-1981). The selection of this year for comparison was based on previous analyses that showed a high correlation between the mortality in the median year of deaths and the calendar periodspecific mortality figures $(17,31)$.

\section{Potential confounders}

The location of the granite workplaces probably excludes exposure to major confounders such as radiation, asbestos or polycyclic aromatic hydrocarbons from organic combustion products (24). Earlier or later confounding occupational exposure can be considered minor because of the stability of the workers' employment in granite work (1). For example, twothirds of the granite workers were still living in their native parish in 1972, and only $7 \%$ of the current granite workers had been employed in other industrial work.

Data on smoking habits were collected by questionnaire during the health screening in 1970-1972. The percentage of nonsmokers was 21 , that of exsmokers 17 , and that of smokers 62 . The smoking habits of the granite workers were thus similar to those of other Finnish groups of active male workers of the same age (3).

\section{Statistical analysis}

In an analysis of the mortality pattern, age-specific observed and expected numbers of deaths and standardized mortality ratios were computed for the causes of death. The observed and expected numbers were subdivided into five-year periods of follow-up and calculated according to years since entry (latency periods). The observed age-specific and cause-specific numbers of deaths were tested by the Poisson distribution model (21) against the corresponding expected numbers on the basis of national figures.

\section{Results}

\section{Comparison of mortality rates for the three} follow-up periods

By the end of the first follow-up in 1972 the number of person-years was 13184 , and 119 deaths had been observed. By the end of the third follow-up (1981) the number of person-years had accumulated to 20165 , and the number of deaths was $235(18,20)$.

Comparison of the mortality results at the end of the three follow-up periods revealed variations in the cause-specific results. The first follow-up in 1972 indicated a slightly higher mortality from respiratory diseases and cancer of the digestive organs than expect- ed on the basis of national rates. The second followup in 1975 confirmed an excess mortality from both types of disease. Mortality from cardiovascular diseases was clearly lower than expected. The third followup in 1981 revealed-increasing mortality from lung cancer. Mortality from respiratory and cardiovascular diseases was similar to the figures determined in the first and second follow-up periods.

\section{Mortality from respiratory diseases}

By the end of 1981, 28 respiratory deaths had been observed; this value was statistically significantly greater than the 13.9 expected (table 1). Of the respiratory diseases, 10 cases were silicotic and 18 nonsilicotic (emphysema, chronic bronchitis, bronchial asthma, and pneumonia) pulmonary diseases. Silicosis was thus the primary cause of death for $4.3 \%$ and a secondary cause of death for $2.6 \%$ of all the deceased. Silicocis as the primary cause of death was connected with lung cancer in only one case, with other respiratory disease in three cases, and with a cardiovascular disease in five cases. Silicosis was considered a secondary cause in the three cases of cardiovascular death (in one of them pulmonary tuberculosis was mentioned as an additional secondary cause), in one case of chronic pyelonephritis, and in one case of pulmonary tuberculosis. In all, tuberculosis of the lung was observed in five cases as the primary cause and in two cases as a secondary cause of death. Apart from the two deaths caused by silicosis but with pulmonary tuberculosis mentioned on the death certificate, pulmonary tuberculosis was also mentioned in connection with different cardiovascular deaths.

\section{Mortality from tumors}

At the end of 1981, the mortality from tumors was nearly the same as that of the general male population (46 observed versus 44.9 expected) (tables 1 and 2). Of the 46 observed tumors, 22 were lung cancer, the corresponding expected number being 17.1. In addition lung cancer was mentioned as a secondary cause

Table 1. Observed $(O)$ and expected $(E)$ numbers of certain causes of death and the standardized mortality ratios (SMR) for the cohort of granite workers at the end of 1981. The period of entry was defined as $1940-1971$.

\begin{tabular}{lrrr}
\hline & \multicolumn{3}{c}{$\begin{array}{c}\text { Numbers of } \\
\text { death }\end{array}$} \\
\cline { 2 - 3 } Cause of death & O & E & SMR \\
\hline All deaths & 235 & 229.7 & 102 \\
Cardiovascular diseases & 100 & 115.5 & 87 \\
Tumors & 46 & 44.9 & 102 \\
$\quad$ Lung cancer & 22 & 17.1 & 129 \\
$\quad$ Cancer of the digestive & 15 & 9.7 & 155 \\
$\quad$ organs & 28 & $13.9^{* * *}$ & 201 \\
Respiratory diseases & 28 & 37.2 & 75 \\
Violent deaths & & & \\
\hline
\end{tabular}

*** $p<0.001$, Poisson distribution. 
Table 2. Mortality from tumors in the cohort from 1940 to 1981 in an age-specific comparison with the expected (E) number of deaths calculated on the basis of death rates for the Finnish male population. $(\mathrm{O}=$ observed number of deaths, SMR = standardized mortality ratio)

\begin{tabular}{|c|c|c|c|c|c|c|c|}
\hline \multirow{3}{*}{$\begin{array}{l}\text { Age } \\
\text { (years) }\end{array}$} & \multirow{3}{*}{$\begin{array}{c}\text { Person- } \\
\text { years }\end{array}$} & \multicolumn{6}{|c|}{ Type of tumor } \\
\hline & & \multicolumn{2}{|c|}{ All } & \multicolumn{2}{|c|}{$\begin{array}{l}\text { Lung } \\
\text { cancer }\end{array}$} & \multicolumn{2}{|c|}{$\begin{array}{l}\text { Cancer } \\
\text { of the } \\
\text { diges- } \\
\text { tive } \\
\text { tract }\end{array}$} \\
\hline & & 0 & $E$ & 0 & $E$ & 0 & $E$ \\
\hline $\begin{array}{l}15-24 \\
25-34 \\
35-44 \\
45-54 \\
55-64 \\
65-74 \\
\geq 75\end{array}$ & $\begin{array}{r}2108 \\
5188 \\
4748 \\
3985 \\
2848 \\
1150 \\
138\end{array}$ & $\begin{array}{r}- \\
- \\
2 \\
5 \\
13 \\
18 \\
8\end{array}$ & $\begin{array}{r}0.2 \\
1.0 \\
3.0 \\
6.5 \\
16.8 \\
14.5 \\
2.9\end{array}$ & $\begin{array}{r}- \\
- \\
- \\
1 \\
6 \\
11 \\
4\end{array}$ & $\begin{array}{l}0.0 \\
0.0 \\
0.4 \\
2.4 \\
7.8 \\
5.8 \\
0.7\end{array}$ & $\begin{array}{l}- \\
\overline{1} \\
- \\
6 \\
5 \\
3\end{array}$ & $\begin{array}{l}0.0 \\
0.2 \\
0.4 \\
1.5 \\
3.1 \\
3.6 \\
0.9\end{array}$ \\
\hline Total & 20165 & 46 & 44.9 & 22 & 17.1 & 15 & 9.7 \\
\hline SMR & & \multicolumn{2}{|c|}{102} & \multicolumn{2}{|c|}{129} & \multicolumn{2}{|c|}{155} \\
\hline
\end{tabular}

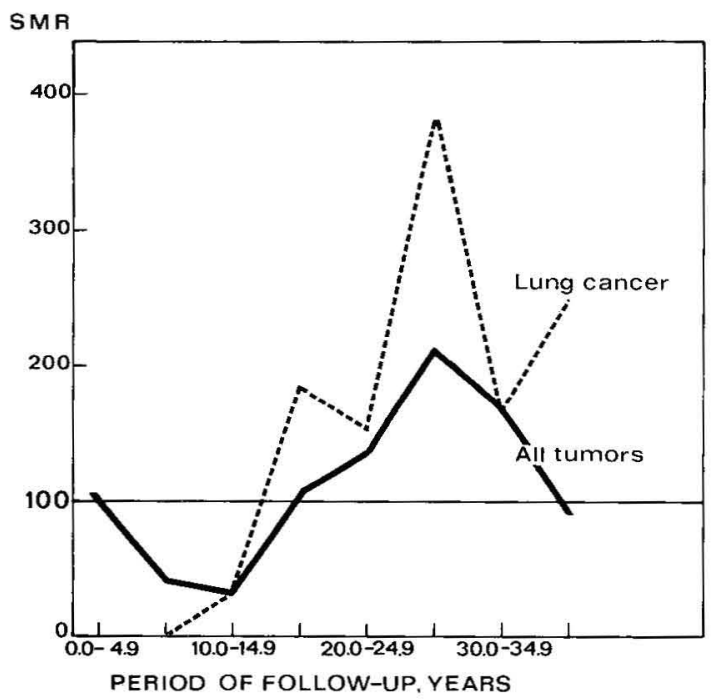

Figure 1. Mortality from tumors in the cohort of granite workers from 1940 to 1981 . Standardized mortality ratios (SMR) for all tumors and lung cancer during different periods of followup.

of death in two cases of coronary heart disease and in one case of suicide.

Mortality from cancer of the digestive organs was 1.6 times the expected value (observed 15, expected 9.7). Nine of these cases were cancer of the stomach, the corresponding expected number being 6.0 , and cancer of the stomach was reported as a secondary cause as well in one other case in connection with a coronary death. The other six were cancer of the esophagus (two cases), cancer of the biliary tract (one case), cancer of the pancreas (one case), and metastatic cancers of undefined origin (two cases). There were no cancers of the colon or rectum.

Altogether, 11 other tumors were reported on the death certificates, nine as primary and two as second-
Table 3. Observed $(\mathrm{O})$ and expected $(E)$ lung cancer deaths according to years since entry into granite work (latency).

\begin{tabular}{lcc}
\hline \multirow{2}{*}{$\begin{array}{l}\text { Years since entry } \\
\text { (latency) }\end{array}$} & \multicolumn{2}{c}{$\begin{array}{c}\text { Lung cancer } \\
\text { deaths }\end{array}$} \\
\cline { 2 - 3 } & $\mathrm{O}$ & $\mathrm{E}$ \\
\hline 15 & 21 & $9.5^{* *}$ \\
20 & 15 & $6.3^{* *}$ \\
25 & 11 & $3.7^{* *}$ \\
30 & 3 & 1.6 \\
\hline${ }^{* *} \mathrm{p}<0.01$, Poisson distribution. & \multicolumn{3}{c}{} \\
\end{tabular}

Table 4. Observed $(O)$ and expected $(E)$ number of lung cancer deaths (based on age-specific figures) according to different periods of follow-up.

\begin{tabular}{lll}
\hline \multirow{2}{*}{$\begin{array}{l}\text { Period of follow-up } \\
\text { (years) }\end{array}$} & \multicolumn{2}{c}{$\begin{array}{c}\text { Lung cancer } \\
\text { deaths }\end{array}$} \\
\cline { 2 - 3 } & $\mathrm{O}$ & $\mathrm{E}$ \\
\hline $0.0-4.9$ & - & 1.7 \\
$5.0-9.9$ & - & 2.6 \\
$10.0-14.9$ & 1 & 3.3 \\
$15.0-19.9$ & 6 & 3.2 \\
$20.0-24.9$ & 4 & 2.6 \\
$25.0-29.9$ & 8 & $2.1^{\star \star}$ \\
$30.0-34.9$ & 2 & 1.2 \\
$\geq 35.0$ & 1 & 0.4 \\
\hline
\end{tabular}

** $p<0.01$, Poisson distribution.

Table 5. Distribution of subtypes of 51 cancer cases based on cancer register data. The cases were observed both as primary and secondary causes of death on the death certificate.

\begin{tabular}{|c|c|}
\hline Type of malignancy & $\begin{array}{c}\text { Number of } \\
\text { patients }\end{array}$ \\
\hline Carcinoma of the lung & 26 \\
\hline $\begin{array}{l}\text { Squamous cell } \\
\text { Small cell } \\
\text { Adenomatous } \\
\text { Poorly differentiated } \\
\text { Unclassified }\end{array}$ & $\begin{array}{r}10 \\
5 \\
2 \\
5 \\
4\end{array}$ \\
\hline $\begin{array}{l}\text { Carcinoma of the gastro- } \\
\text { intestinal tract }\end{array}$ & 16 \\
\hline $\begin{array}{l}\text { Esophagus } \\
\text { Stomach } \\
\text { Pancreas } \\
\text { Biliary duct } \\
\text { Metastatic carcinoma }\end{array}$ & $\begin{array}{l}3 \\
9 \\
1 \\
1 \\
2\end{array}$ \\
\hline $\begin{array}{l}\text { Carcinoma of the prostate } \\
\text { Carcinoma of the kidney } \\
\text { Astrocytoma } \\
\text { Hodgkin's disease } \\
\text { Reticulocellular sarcoma } \\
\text { Metastatic carcinoma }\end{array}$ & $\begin{array}{l}3 \\
1 \\
1 \\
1 \\
1 \\
2\end{array}$ \\
\hline Total & 51 \\
\hline
\end{tabular}

ary causes (one in connection with lung cancer). These tumors were not predominantly of any particular type of cancer.

The mortality rate according to years since entry into granite work (latency phases) revealed an excess mortality from tumors in the group of workers followed for 20 years or more (table 3 ). When analyzing differ- 
ent periods of follow-up, we found the greatest excess for the period of $25-29$ years (observed 11, expected 5.2 , p $<0.05$ ) (figure 1 ). The excess was mainly caused by lung cancer (observed 8 , expected 2.1, p $<0.01$ ) (figure 1 and table 4). Gastrointestinal cancer was observed mainly during two periods of follow-up, ie, $0-5$ and $20-25$ years.

\section{Case analysis of patients with cancer}

All 51 cases with cancer as a primary or secondary diagnosis on the death certificate were studied from available cancer register data. The different types of malignant neoplasms are shown in table 5. Thirty-five cases $(69 \%)$ out of 51 had either cancer of the lung or of the stomach, whereas about $35 \%$ of all cancers in the Finnish male population are cancers of the lung or of the stomach (26).

\section{Discussion}

The present study showed an excess mortality from lung cancer among granite workers exposed to pure silica dust.

Earlier cohort studies of workers exposed to pure silica are few and have been inconclusive. They have indicated either a decreased or only slightly increased risk of lung cancer $(6,29)$. However, both cohort and case-referent studies of coal miners have repeatedly shown a statistically significant excess of gastrointestinal cancer $(2,23,27)$. On the other hand, a number of cohort studies on workers exposed predominantly to crystalline silica in mines or foundries suggest an excessive risk of bronchogenic cancer $(5,8,9,14,15$, $22,31)$. However, in these exposure cohorts the causative role of silica exposure is not indisputable, as potential occupational exposures to other carcinogens have often occurred simultaneously (radon daughters, asbestos, polycyclic aromatic hydrocarbons).

Proportional mortality results derived from cohorts of silicotic patients have shown excess lung cancer ( 7 , $10,28,33)$. These cohorts mainly comprised workers with some other occupational exposure (eg, miners, foundry workers) and mixed groups (quarrying, mining, and tunneling). A case-referent study of silicotic patients has shown an increased lung cancer risk for smokers, but no increase for nonsmokers (35). However, excess mortality from lung cancer has been reported in a cohort study of silicotic stone workers exposed to pure silica (10). Steenland \& Beaumont (29) also found an excess risk of lung cancer among a subgroup of silicotic patients who had been exposed to pure silica. On the other hand, no association between silicosis and lung cancer was found among silicotic gold miners (11).

The inconsistency of the mortality results of these different studies may depend on differences in exposure (including concomitant carcinogenic exposures), study design, and methods of analysis. Thus even the same exposure cohort may give different results depending on how it is analyzed $(17,18)$. Similarly, a cohort of silicotic patients does not necessarily produce mortality rates consistent with those derived from an exposure cohort $(18,19)$.

The cohort of the present study comprised outdoor granite workers exposed to relatively pure silica. They were not exposed to other carcinogens that could confound the outcome. The smoking habits of the granite workers did not essentially deviate from those of Finnish industrial male workers (3). The observed rate ratios for lung cancer during follow-up periods of 15 years to more than 35 years varied between 1.7 and 3.8. These ratios cannot even theoretically be explained by asymmetrical smoking alone because its maximal confounding effect would not be more than about twofold, in practice much less (4). Neither could regional variations confound the observed cancer rates because the three study regions are districts with medium levels of lung and stomach cancer incidence (26). Hence we conclude that the lung cancer excess observed cannot be ascribed to the confounding effect of smoking.

Compared with previous cohort studies on pure silica exposure, the present one found a higher risk of lung cancer. We believe that this difference is due to the use of an optimum composition of the periods of entry, the periods of follow-up and the age structure of the cohort for revealing excess mortality from lung cancer $(12,17)$.

Even though the periods of exposure (mean 12 years) and follow-up were long, the period-specific mortality ratios for cancer are probably underestimates. Information about the time of first exposure was based on employers' personnel records. However, preliminary results from a current questionnaire study of these workers has revealed that the period of exposure in granite work in fact was longer than that evident from employers' rolls. This difference may explain the unexpected number of deaths from gastrointestinal cancer found for $0-5$ years of follow-up. The different follow-up periods at which lung cancer and gastrointestinal cancer were observed may be due to chance or caused by social factors, or they may point to different latency phases and/or variable cellular proliferation rates of cancer of the lung and the digestive tract.

The aforementioned studies do not indisputably provide evidence for or against a causal association between silica exposure and lung cancer. Whether the association found in several studies is based on the effect of quartz dust per se or on the fibrotic silicosis process is also unclear. The interpretation of the results has often been confused by methodological complexity.

The present study suggests that silica exposure per se may influence the development of lung cancer. First, the periods of exposure and follow-up were sufficiently long in this study to reveal both silicosis and cancer. 
Silicosis was not very common. Second, if the development of lung cancer requires a silicotic process, it is remarkable that only one lung cancer patient had silicosis (lung cancer was a secondary cause of death, ie, not included in the statistical calculations). Third, increased mortality from cancer of extrapulmonary sites ('́astrointestinal cancer) (table 4), as well as certain nonmalignant disease patterns (18), further support a direct carcinogenic effect of silica exposure per se.

Hence, these mortality results support the hypothesis of an association between silica exposure as such and lung cancer. The reason earlier cohort studies on exposure to pure silica have been negative or only slightly positive with respect to cancer occurrence may presumably be related to methodological factors. In addition, a number of animal studies indicate that pure silica can both promote and directly induce lung and other tumors $(30,32)$. The International Agency for Research on Cancer concluded in June 1986 that there is "limited evidence" for the carcinogenity of crystalline silica to humans (13).

\section{Acknowledgments}

Ms R Vuorela collected the data from the employers' records, Ms T Suomela obtained the hospital register data, and R Luukkonen, MSc, assisted with the data processing. We express our sincerest thanks to them all. We are also grateful to T Nyrke, MD, for his assistance in gathering district medical records.

We thank the Social Insurance Institution for the disability data, the Central Statistical Office of Finland for the data on causes of death, and the Finnish Cancer Registry for the cancer mortality data.

\section{References}

1. Ahlman K, Backman A-L, Hannunkari I, Järvinen E, Koponen E, Koskela R-S, Partanen T, Seppäläinen A-M, Starck J. Kivityöntekijöiden työolosuhteet ja terveydentila [Work conditions and health of granite workers]. Social Insurance Institution, Helsinki 1975. (Kansaneläkelaitoksen julkaisuja AL: 4/1975) (English summary).

2. Armstrong BK, McNulty JC, Levitt LJ, Williams KA, Hobbs MST. Mortality in gold and coal miners in Western Australia with special reference to lung cancer. $\mathrm{Br}$. J Ind Med 36 (1979) 199-205.

3. Asp S. Confounding by variable smoking habits in different occupational groups. Scand J Work Environ Health 10 (1984) $325-326$.

4. Axelson $O$. Aspects on confounding in occupational health epidemiology. Scand J Work Environ Health 4 (1978) $85-89$.

5. Axelson $O$, Sundell L. Mining, lung cancer and smoking. Scand J Work Environ Health 4 (1978) 46-52.

6. Davis LK, Wegman DH, Monson RR, Froines J. Mortality experience of Vermont granite workers. Am J Ind Med 4 (1983) $705-723$.

7. Finkelstein M, Kusiak R, Suranyi G. Mortality among miners receiving workmen's compensation for silicosis in Ontario: $1940-1975$. J Occup Med 24 (1982)
$663-667$

8. Fox AJ, Goldblatt P, Kinlen LJ. A study of the mortality of Cornish tin miners. B J Ind Med 38 (1981) $378-380$

9. Goldsmith DF, Guidotti TL, Johnston DR. Does occupational exposure to silica cause lung cancer? Am J Ind Med 3 (1982) 423-440.

10. Gudbergsson H, Kurppa K, Koskinen H, Vasama M. An association between silicosis and lung cancer: A register approach. In: Bergbau-Berufsgenossenschaft. Proceedings of the VIth International Pneumoconiosis Conference, Bochum, FRG, September 21-24 1983. Volume 1. Bochum 1984, pp 212-216.

11. Hessel PA, Sluis-Cremer GK. Case-control study of lung cancer and silicosis. In: Goldsmith DF, Winn DM, Shy CM, ed. Silica, silicosis and cancer: Controversy in occupational medicine. Praeger Publishers, New York, NY 1986, pp 351-355. (Cancer research monographs, volume 2).

12. Hoel DG. The impact of occupational exposure patterns on quantitative risk estimation. In: Cold Spring Harbor Laboratory. Risk quantification and regulatory policy. Cold Spring Harbor, NY 1985, pp 105-118. (Banbury report no 19 ).

13. International Agency for Research on Cancer. Silica and some silicates. Lyon (in press). (IARC monographs on the evaluation of the carcinogenic risk of chemicals to humans, volume 42).

14. Katsnelson BA, Mokronosova KA. Non-fibrous mineral dusts and malignant tumors. J Occup Med 21 (1979) $15-20$.

15. Koskela R-S, Hernberg S, Kärävä R, Järvinen E, Nurminen M. Mortality study of foundry workers. Scand J Work Environ Health 2 (1976): suppl 1, 73-89.

16. Koskela R-S, Järvinen E. Kivityöntekijöiden kuolleisuus, työkyvyttömyys, sairastavuus sekä työntekijöiden mielipiteet kivityöhön liittyvistä terveydellisistä ongelmista. [Mortality, disability and health among granite workers]. In: Ahlman K, Backman A-L, Hannunkari I, Järvinen E, Koponen M, Koskela R-S, Partanen T, Seppäläinen AM, Starck J, ed. Kivityöntekijöiden työolosuhteet ja terveydentila [Work conditions and health of granite workers]. Social Insurance Institution, Helsinki 1975. (Kansaneläkelaitoksen julkaisuja AL 4: 1975).

17. Koskela R-S, Järvinen E, Kolari PJ. Effect of cohort definition and follow-up length on occupational mortality rates. Scand J Work Environ Health 10 (1984) $311-316$.

18. Koskela R-S, Klockars M, Järvinen E, Kolari PJ, Rossi A. Mortality and disability among granite workers. Scand J Work Environ Health 13 (1987) 18-25.

19. Kurppa K, Gudbergsson H, Hannunkari I, Koskinen H, Hernberg S, Koskela R-S, Ahlman K. Lung cancer among silicotics in Finland. In: Goldsmith DF, Winn DM, Shy CM, ed. Silica, silicosis and cancer: Controversy in occupational medicine. Praeger Publishers, New York, NY 1986, pp 311-319. (Cancer research monographs, volume 2).

20. Kurppa K, Koskela R-S, Gudbergsson H. Gastrointestinal cancer in workers exposed to quartz. Lancet 1 (1982) 150.

21. Lentner C, ed. Geigy scientific tables. Volume 2. Eighth edition. Ciba-Geigy Limited, Basel 1982.

22. Milham S Jr. Occupational mortality in Washington state, 1950-1971. US Government Printing Office, Washington, DC 1976. (DHEW (NIOSH) publication no $76-175-\mathrm{A})$.

23. Miller BG, Jacobsen M. Dust exposure, pneumoconiosis, and mortality of coalminers. Br J Ind Med 42 (1985) $723-733$

24. Mustonen R. Suomalaisten rakennusmateriaalien luonnollinen radioaktiivisuus [Natural radioactivity of Finnish building materials]. Finnish Institute of Radiation 
Protection, Helsinki 1978. (Säteilyturvakeskuksen raporttisarja STL-BIO).

25. National Board of Health. Tauti- ja kuolinsyyluokitus [WHO. The international statistical classification of diseases, injuries and causes of death]. Helsinki 1969.

26. Pukkala E, Rimpelä A, Läärä E. Syöpä Suomessa [Cancer in Finland]. The Finnish Cancer Registry, Helsinki 1982.

27. Rockette HE. Cause specific mortality of coal miners. J Occup Med 12 (1977) 795-801.

28. Schüler G, Rüttner J. Silicosis and lung cancer in Switzerland. In: Goldsmith DF, Winn DM, Shy CM, ed. Silica, silicosis and lung cancer: Controversy in occupational medicine. Praeger Publishers, New York, NY 1986, pp 357-366. (Cancer research monographs, volume 2).

29. Steenland K, Beaumont J. A proportionate mortality study of granite workers. Am J Ind Med 9 (1986) $189-201$.

30. Stenbäck F, Rowland J. Experimental respiratory carcinogenesis in hamsters. Oncology 26 (1979) 63-71.
31. Tola S, Koskela R-S, Hernberg S, Järvinen E. Lung cancer mortality among iron foundry workers. J Occup Med 21 (1979) $753-760$.

32. Wagner MMF, Wagner JC, Davies R, Griffiths DM. Silica-induced malignant histiocytic lymphoma: Incidence linked with strain of rat and type of silica. $\mathrm{Br} \mathrm{J}$ Cancer 41 (1980) 908-917.

33. Westerholm P. Silicosis: Observations on a case register. Scand J Work Environ Health 6 (1980): suppl 2 , $1-86$.

34. World Health Organization. World health statistics annual 1972: Vital statistics and causes of death. Geneva 1987.

35. Zambon $\mathbf{P}$, Mastrangelo G, Saia B. Exposure to silica and lung cancer, a case-control study. Presented at the Montreal Conference on Occupational Health, 23-25 August 1983.

Received for publication: 10 June 1986 